\title{
Microfinance Credit Accessibility and Financial Performance of Small and Medium Enterprises in Machakos County, Kenya
}

\author{
Muema Joseph Mungutia, Lucy Wamugo ${ }^{b}$ \\ ${ }^{a, b}$ Kenyatta University, Kenya \\ zahramppa@gmail.com
}

\begin{abstract}
SMEs in Machakos County have been characterized by poor financial performance which has been linked to financial access. Financial access is one of the keys that drive the development of SME in the country, particularly access to bank financing since banking sector plays a key role in serving this segment. This study specifically sought to determine the influence of collateral security, loan-income ratio and geographical branch penetration on financial performance of SMEs. Study adopted census survey due to small population size. Respondents were supplied with semi-structured questionnaires with aim of getting their views regarding financial accessibility and SME performance. Findings of the study indicated that collateral security, loan-income ratio, and geographical branch penetration has a significant positive effect on financial performance in Machakos County, Kenya. This research recommends that SME's should improve their core capital, strengthen their financial management practices, foster financial innovation, and literacy within firms.
\end{abstract}

Article Info

- Received : October 26, 2019

- Revised : January 12, 2020

- Published : January 18, 2020

- No. Pages : 71-79

- DOI : 10.33019/ijbe.v4i1.250

- JEL : H81, L32, O16

- Keywords : financial performance, SMEs, geographical penetration, collateral security

\section{Introduction}

In recent years, economists and policymakers around the world working on economic and financial development are increasingly interested in topic of financing of SMEs. This is mainly because SMEs play a big role in economy and they account for the lion's share of firms operating in the country and contribute largely to employment (Abayo \& Oloko, 2017). Most big and influential companies around the world mainly start as SMEs underlining importance of financing them since in the future, through investment and diversification, they could develop and become key contributors to economy (Badulescu, 2012). Academicians and policymakers have brought topic of SME financing due to perception that SMEs lack appropriate financing and need financing and support from government programs. Githui (2012) observed that difference between failed and successful SMEs was in their ability to access finances.

World Bank (2015) estimates that $70 \%$ of all SMEs in developing economies lack access to credit facilities making it difficult for them to survive. In as much as the gap varies significantly between regions and countries, it is particularly wide in Africa and Asia. In Africa, access to 
credit gap for formal SMEs was estimated to be US\$ 1.2 trillion, while credit gap for informal SMEs stood at US\$ 1.4 trillion. World Bank study further suggests that between 365-445 million SMEs are in emerging markets, out of which, about 30 million are formal SMEs; about 70 million are formal micro-enterprises, and about 345 million are informal enterprises. Continued development of SMEs is at the core of entrepreneurship in Kenya and is a global focus of creation of employment and generation of wealth (Onaolapo, 2014). It is important to note that currently, youth in Kenya can get reasonable employment opportunities by setting up their businesses with help from MFIs and government funding (Kithinji, 2010). However, according to Azende (2014), one issue affecting the development of SMEs in Kenya is access to micro-finance. However, most stakeholders are aware that SME access to finances is particularly limited and this limits their ability to remain competitive (Wanjohi, 2010). This notwithstanding, Gichuki, Njeru, and Tirimba, (2014) posit that the best source of new SME financing is through entrepreneurs' funds. Researcher further points out that assess to microfinance credit and financing options can foster the financial performance of SMEs in Kenya. According to Vera and Onji (2010), SMEs in Europe regularly provide financial information to business developers and start-ups as a way of enhancing access to financial credit compared to developing nations. Thus, there exists a positive correlation between streamlined financial information between borrowers and borrowers, and SMEs access to finance (Wanjohi, 2010).

Government of Kenya sees the development of SME as one of the means of achieving socioeconomic objectives which include alleviation of poverty (Onaolapo, 2012). However, for SME to become more productive, access to finance necessary for investment is crucial. SMEs fail due to their inability to access funds necessary to expound their portfolio and adopt new technologies, decreasing chances of survival in a highly competitive environment (Shah \& Braganza, 2013). Azende (2012) investigated carried out a study on the effects of collateral requirements by banks on SMEs in Nigeria. Reports concluded indicated that the existence of a rigid collateral requirement policy, SMEs in the region struggled to access financial services of banks. However, a study by Azende (2012) did not focus on the effects of access to financial services on the performance of Nigerian SMEs; a gap which this study sought to fill. Ghimire and Abo (2013) investigated factors that affect financial availability to SMEs in Cote D'Ivoire. Their study collected data from Small Medium Enterprises which were located in both rural and urban areas. Analysis was carried out with use of probability sampling, cross-tabulation and correspondence analysis techniques. Study found banks limit money available to SMEs due to irregularity of available information and lack of valuable collateral. However, the study failed to give a clear link between the accessibility of credit and financial performance of SMEs; a gap current study sought to fill. Based on explanation above, this study will determine influences of collateral security, loan income, and geographical branch penetration toward the financial performance of SMEs in Machakos County, Kenya.

\section{Literature Review}

Quartey et al. (2017) researched factors that limit SME financing in ECOWAS countries. Their study focused on SMEs in West Africa with data being drawn from the World Bank Enterprise Survey data set. Study employed descriptive, correlation and regression analysis in analysis of collected research data. Findings of the study showed that main constructs of access to financing are firm size, depth of credit information and strength of their security. However, the study focused on a country review whereas current study was limited to a devolved county juristic context. Abayo and Oloko, (2017) examined influences that access to credit has on the development of SMEs in Kisumu County, Kenya. Descriptive research design adopted focused 
on 332 small business enterprises in selected market. Thus research utilized a semi-structured questionnaire collection process. Descriptive statistics were used to analyze the collected data. Results of research indicated that increasing publicity on availability of micro-credit products as well as enhancing their accessibility to Small Business Enterprises enhanced their growth. Research focused on business growth whereas the current study examined the financial performance metrics in general.

Waari and Mwangi (2015) studied factors that influence SME access to finance in Meru County, employed a descriptive research design with both qualitative and quantitative techniques being utilized in data collection and analysis respective. It concluded that $47 \%$ of SME's have high credit risk exposure. This is because they are likely to have more than two loans and the lender may not be aware of this fact and as a result, will not approve financing to SMEs. They focused on MSME whereas current research focuses on SME in Machakos County. Muguchu (2013) investigated relationship between credit access and performance of Kenyan SMEs, focused on imperfect information theory and obtained secondary data from SME financial records between 2008 and 2012. It analyzed data collected using both descriptive and regression analysis. Both analyses found a positive relationship between income-loan ratio and return on investment for SMEs. However, study used secondary data only, a gap current study seeks to fill. Kanyare and Mungai (2017) examined influences of determinants of financial access on the performance of SMEs in Wajir County, Kenya. Research adopted a descriptive research design and targeted all the 5000 SMEs in Wajir County and utilized quantitative research data collected using a self-administered questionnaire. Moreover, findings indicated that loan structuring and geographical accessibility to microfinance institutions positively affected the financial performance of SME's in Wajir County. Research focused on SMEs in Wajir County whereas the current study was conducted in Machakos County. Based on previous studies above, there are several hypotheses proposed, as follows:

H1: Collateral security has positive influence on financial performance.

$\mathrm{H} 2$ : Loan income ratio has positive influence on financial performance.

H3: Geographical Branch Penetration has positive influence on financial performance.

\section{Research Methods}

Research design refers to an outline plan that is used as a research study by a researcher for purposes of generating answers to research questions (Mugenda, 2013). Study adopted descriptive research design. Population was chosen since as business owners/managers they were at a place to offer relevant and reliable information needed to solve research problem. Population of registered SMEs in Machakos County is approximately 185. Study adopted a census sampling technique in drawing sample respondents. This ensured there was equal representation across all respondents. Study used a sample of 185 managers/owners of all SME's within Machakos County. Primary data from entrepreneurs or managers of SMEs was collected using semi-structured questionnaires. Questionnaires were preferred for this study since it can collect large amounts of data in a short time. Researcher employed selfadministration approach of data collection. Researcher monitored the process personally to ensure that questionnaires were filled by intended people and that recordings were responded to proper respondents.

Quantitative data were analyzed using descriptive analysis and inferential analysis techniques with the help of Statistical Packages for Social Sciences (SPSS Version 23). Descriptive analysis included percentage, frequencies, means and standard deviations on research variables. Inferential statistics will include multiple regression analysis and correlation to 
estimate the level of association between research variables. Analyzed data was presented using charts and tables as well as other infographics deemed appropriate.

The regression equation was as follows:
Y : Financial Performance (Profitability) of SME
$ß 1-\beta 3$ : Coefficient of the independent variable
$\mathrm{X} 1$ : Collateral Security
X2 : Loan Income ratio
X3 : Geographical Branch Penetration
$\varepsilon \quad$ : error term

Where:

$\mathrm{Y}=\beta 0+\beta 1 \mathrm{X} 1+\beta 2 \mathrm{X} 2+\beta 3 \mathrm{X} 3+\varepsilon$

\section{Results}

\section{Descriptive Analysis}

According to results, response rate for the study was $77 \%$ of total sample size and non-response was $23 \%$. This is sufficient enough according to (Graham, 2002) who ascertained that a response rate above $30 \%$ to $50 \%$ of total sample size is sufficient enough to be considered to represent opinions of respondents in target population. Descriptive statistics enables the study to meaningfully describe a distribution of scores or measurements using indices or statistics. Type of statistics or indices used depends on the type of variables and scale of measurements used in this study. Commonly used measures are percentages, mode, mean and median. This study will present its findings in the form of mean. This research wants to determine influences of collateral security on the financial performance of SMEs in Machakos County.

Table 1. Collateral Security Descriptive Analysis

\begin{tabular}{lccccccc}
\hline & NA & SE & ME & LE & VE & Mean & Std.dev \\
\hline $\begin{array}{l}\text { Assets owned by the business cannot be } \\
\text { used as security for a good loan. }\end{array}$ & 0 & 3.7 & 22.2 & 51.9 & 22.2 & 3.93 & .78 \\
\hline $\begin{array}{l}\text { Business has a strict policy not to use } \\
\text { assets as security for loans }\end{array}$ & 0 & 4.3 & 7.4 & 48.1 & 44.4 & 4.37 & .63 \\
\hline $\begin{array}{l}\text { Business has failed to obtain loans } \\
\text { severally due to lack of guarantors }\end{array}$ & 0 & 3.7 & 33.3 & 33.3 & 29.6 & 3.89 & .89 \\
\hline $\begin{array}{l}\text { Group security has enabled the SME to } \\
\text { obtain loans with other SMEs in the area }\end{array}$ & 0 & 3.7 & 25.9 & 33.3 & 37.0 & 4.03 & .89 \\
\hline $\begin{array}{l}\text { Previous experience with the use of } \\
\begin{array}{l}\text { collateral security discourages my } \\
\text { business from obtaining loans }\end{array}\end{array}$ & 0 & 33.3 & 29.6 & 25.9 & 11.1 & 3.70 & .99 \\
\hline
\end{tabular}

Note: Na: Not at all; SE: Small extent; ME: Medium extent; LE: Large extent; VE: Very large extent

Source: Data analysis

Respondents agreed that company-owned assets cannot be used as security for a good loan as shown by a mean value of 3.93 and a standard deviation of .78 indicating moderate dispersion in the results. These results are consistent with Quartey, Turkson, Abor, and Iddrisu, (2017) who indicated that poor assets led to a denial of loans among SME's. respondents agreed that businesses have strict policies which prevent firm from using its assets as securities for loans as indicated by a mean of 4.37 and deviation of .63 indicating minimal dispersion in responses. findings indicating agreement among respondents concerning business has failed to obtain loan severally due to lack of guarantors as indicated by a mean of 3.89 and a deviation. above findings are consistent with Ghimire and Abo (2013) who showed that lack of adequate collateral and limited firm information limited access to credit. findings also show a strong 
agreement among respondents that group security has enabled SME to obtain loans with other SME's in the area as shown by a mean of 4.03 and a deviation of .89. results showed that previous experience with the use of collateral discourages business from obtaining loans as indicated by a mean of 3.7. These results are supported by Waari and Mwangi (2015) who concluded that poor credit risk profile reduced chances of obtaining financing among MSME. A Likert scale was used to determine the extent to which respondents agreed with statements on how Loan-Income Ratio affects the financial performance of SMEs in Machakos County.

Table 2. Loan-Income Ratio Descriptive Analysis

\begin{tabular}{lccccccc}
\hline & NA & SE & ME & LE & VE & Mean & Std.dev \\
\hline $\begin{array}{l}\text { Microfinance cap on income do not } \\
\text { favour SMEs credit acquisition }\end{array}$ & 0 & 0 & 25.9 & 37.0 & 37.0 & 4.11 & .80 \\
\hline $\begin{array}{l}\text { Lack of standard agreed loan income } \\
\text { ratio across banks for microfinance } \\
\text { product leads to low credit uptake by } \\
\text { SMEs }\end{array}$ & 0 & 7.4 & 29.6 & 14.8 & 48.1 & 4.04 & 1.06 \\
\hline $\begin{array}{l}\text { Banks around have microfinance } \\
\text { platforms that have very fair loan- } \\
\text { income ratio requirements }\end{array}$ & 0 & 11 & 29.7 & 29.6 & 29.6 & 3.78 & 1.01 \\
\hline $\begin{array}{l}\text { Income-loan ratio requirement } \\
\text { encourages business growth for most }\end{array}$ & 3.7 & 14.8 & 18.5 & 44.4 & 18.5 & 3.59 & 1.08 \\
\begin{tabular}{l} 
SMEs \\
\hline $\begin{array}{l}\text { Microfinance rules and regulations } \\
\text { hinder capital acquisition for SMEs }\end{array}$
\end{tabular} & 3.7 & 18.5 & 33.3 & 37.0 & 7.4 & 3.26 & .98 \\
\hline
\end{tabular}

Note: Na: Not at all; SE: Small extent; ME: Medium extent; LE: Large extent; VE: Very large extent

Source: Data analysis

On microfinance cap on income, a mean of 4.11 showed that most of respondents agreed that cap does not favour SME credit acquisition. Concerning lack of standard agreed loan income ratio across banks for microfinance product leads to low credit uptake by SMEs, a mean of 4.04 showed agreement and a deviation of 1.06 indicating high dispersion. These results are in line with Amoah, Aboagye, Bokpin, and Ohene-Asare (2018) who concluded that low-income generation had a negative effect on credit access. Iopev and Kwanum (2012) also indicated that effective management of income-loan portfolio had a positive effect on credit acquisition. With regard to the banks around have microfinance platforms that have very fair loan-income ratio requirements, respondents agreed as indicated by a mean of 3.78 and a deviation of 1.01 . Concerning income-loan ratio requirement encourages business growth for most SMEs, respondents agreed as indicated by a mean of 3.59 and a deviation of 1.08. Concerning Microfinance rules and regulations hindering capital acquisition for SMEs, a mean of 3.26 showed agreement and a deviation of .98. Muturi and Rotich (2016) showed that failure to meet credit requirements had a negative effect on credit access. The third objective of the study sought to find out whether respondents agreed with influences of Geographical Branch Penetration on the financial performance of SMEs in Machakos County.

Table 3. Geographical Branch Penetration Descriptive Analysis

\begin{tabular}{lccccccc}
\hline & NA & SE & ME & LE & VE & Mean & Std.dev \\
\hline $\begin{array}{l}\text { Distance between SME and bank is } \\
\text { very significant for its credit access } \\
\text { hence performance }\end{array}$ & 3.7 & 7.4 & 22.2 & 40.7 & 25.9 & 3.78 & 1.05 \\
\hline $\begin{array}{l}\text { Qualification and access to loans is } \\
\text { based on long term-built linkage with } \\
\text { banks in SME locality }\end{array}$ & 3.7 & 3.7 & 29.6 & 25.9 & 37.0 & 3.89 & 1.09 \\
\hline
\end{tabular}




\begin{tabular}{lccccccc}
\hline $\begin{array}{l}\text { Certain loans are a reserve of SMEs ho } \\
\text { operate near particular areas or banks }\end{array}$ & 0 & 18 & 29.6 & 22.7 & 29.6 & 3.63 & 1.11 \\
\hline $\begin{array}{l}\text { Branch managers often give loans to } \\
\begin{array}{l}\text { SMEs based on favouritism due to ease } \\
\text { of access and monitoring }\end{array}\end{array}$ & 3.7 & 7.4 & 25.9 & 25.9 & 37.0 & 3.85 & 1.13 \\
\hline $\begin{array}{l}\text { Bank accessibility affects microfinance } \\
\text { loaning to SMEs }\end{array}$ & 7.4 & 7.4 & 29.6 & 29.6 & 25.9 & 3.59 & 1.19 \\
\hline
\end{tabular}

Note: Na: Not at all; SE: Small extent; ME: Medium extent; LE: Large extent; VE: Very large extent Source: Data analysis

Findings of the research indicated that concerning the distance between SME and bank is very significant for its credit access hence performance. respondents agreed as indicated by a mean of 3.78 and a deviation of 1.05. These results are not consistent with Nkuah. Tanyeh and Gaeten (2013) concluded that relationship between the location of business and access to credit was insignificant. results also indicated there was an agreement concerning qualification and access to loans is based on long term-built linkage with banks in SME locality as indicated by a mean of 3.89. Concerning certain loans are a reserve of SMEs who operate near particular areas or banks, a mean of 3.63 showed agreement and a deviation of 1.11. These results are in line with Minh (2012) who indicated that access to financing was determined by the business location. With regard to branch managers often give loans to SMEs based on favouritism due to ease of access and monitoring, a mean of 3.85 showed agreement and a deviation of 1.13. Concerning Bank accessibility affects microfinance loaning to SMEs, a mean of 3.59 showed agreement and a deviation of 1.19 indicating moderate dispersion in responses obtained. above findings are in line with Kanyare and Mungai (2017) who concluded that geographical accessibility had a positive influence on accessing micro-credit among SME's. The study sought to find out the level of agreement with statements regarding influences of the financial performance of SMEs.

Table 4. Financial Performance Descriptive Analysis

\begin{tabular}{lccccccc}
\hline & NA & SE & ME & LE & VE & Mean & Std.dev \\
\hline Targeted profits have been met & 0 & 3.7 & 29.6 & 40.7 & 25.9 & 3.89 & .85 \\
\hline Liquidity has been impressive & 0 & 3.7 & 33.3 & 33.3 & 29.6 & 3.89 & .89 \\
\hline Targeted sales volumes have been met & 3.7 & 14.8 & 18.5 & 44.4 & 18.5 & 3.59 & 1.08 \\
\hline
\end{tabular}

Note: Na: Not at all; SE: Small extent; ME: Medium extent; LE: Large extent; VE: Very large extent

Source: Data analysis

Concerning the SME has achieved targeted profits, a mean of 3.89 showed agreement and deviation of .85 indicating minimal dispersion. With regard to liquidity respondents, agreed as indicated by a mean of 3.89. Concerning targeted sales volume have been achieved, a mean of 3.59 showed agreement. These results are in congruence with (Abayo \& Oloko, 2017; Gichuki, Njeru, \& Tirimba, 2014; Muturi \& Rotich, 2016) who indicated there has been a spur in the growth of SME firms within country in terms of asset growth, profitability and meeting sales targets as well as their employability levels.

\section{Inferential Analysis}

A multiple regression analysis was carried out to determine the influences of microfinance credit accessibility on the financial performance of SMEs in Machakos County. Statistical package SPSS, was used to in the data entry and computation of data and regression analysis is presented below:

Table 5. Regression Model Summary

\begin{tabular}{ccccc}
\hline Model & R & R Square & Adjusted R Square & Std. Error of the Estimate \\
\hline 1 & $.752^{\mathrm{a}}$ & .565 & .796 & .89757 \\
\hline
\end{tabular}


Predictors: (Constant) collateral security, loan-income ratio, and geographical branch penetration.

Source: SPSS output

From above regression, 56.5\% variations in the financial performance of SME's can be explained by collateral security, loan-income ratio, and geographical branch penetration as indicated by R Square $=.565$. These results are consistent with (Abayo \& Oloko, 2017; Kanyare $\&$ Mungai, 2017) who indicated a positive effect on the financial performance of SME's.

Table 6. ANOVA Summary

\begin{tabular}{llccccc}
\hline \multicolumn{2}{c}{ Model } & $\begin{array}{c}\text { Sum of } \\
\text { Squares }\end{array}$ & df & $\begin{array}{c}\text { Mean } \\
\text { Square }\end{array}$ & F & Sig. \\
\hline \multirow{2}{*}{1} & Regression & 10.686 & 4 & 2.671 & 16.478 & $0.00^{\mathrm{b}}$ \\
\cline { 2 - 7 } & Residual & 81.193 & 317 & 3.56 & & \\
\cline { 2 - 7 } & Total & 91.879 & 321 & & & \\
\hline
\end{tabular}

Predictors: (Constant) collateral security, loan-income ratio, and geographical branch penetration.

Source: SPSS output

Results indicated that f-statistic $=16.478, \mathrm{p}$-value $=.000<.05$. This indicates that the model was statistically significant and fit in explaining influences on the financial performance of SME in Machakos County.

Table 7. Regression Coefficients

\begin{tabular}{lccccc}
\hline & $\begin{array}{c}\text { Unstandardized } \\
\text { Coefficients }\end{array}$ & & $\begin{array}{c}\text { Standardized } \\
\text { Coefficients }\end{array}$ & $\mathrm{t}$ & Sig. \\
\cline { 2 - 7 } & $\mathrm{B}$ & Std. Error & Beta & & \\
\hline (Constant) & -.255 & .864 & & -.296 & .769 \\
\hline Collateral security & .468 & .281 & .131 & 3.573 & .001 \\
\hline Loan-income ratio & .465 & .207 & .308 & 2.247 & .002 \\
\hline $\begin{array}{l}\text { Geographical branch } \\
\text { penetration }\end{array}$ & .322 & .151 & .262 & 2.132 & .001 \\
\hline
\end{tabular}

Source: SPSS output

Regression result equation:

$$
Y=-.255+.281 X 1+.207 X 2+.151 X 3+.864
$$

Regression equation above indicates that; there is a positive and significant effect of collateral security on the financial performance of SME in Machakos County as indicated by $\beta=.281$, sig $=.001<.005(\mathrm{H} 1:$ Accepted $)$. regression equation above further indicates that; there is a positive and significant effect of loan income ratio on the financial performance of SME in Machakos County as indicated by $\beta=.207, \mathrm{sig}=.002<.005$ (H2: Accepted). regression equation above further indicates that; there is a positive and significant effect of geographical branch penetration on the financial performance of SMEs in Machakos County as indicated by $\beta=.151$, sig $=.001<.005(\mathrm{H} 3:$ Accepted $)$.

\section{Conclusion and Recommendation}

\section{Conclusion}

Collateral values of applicants were categorized within stages of no collateral to high collateral. Findings revealed that information asymmetry and inadequate collateral limit flow of credit from banks to SMEs which in turn affect performance. Study concludes that SME's within the county should enhance hold assets or other physical instruments that can be utilized as 
collateral. Finally, study concludes that a lack of adequate financing plays a significant role in SMEs financial performance. Credit from microfinance institutions is key to the growth of SMEs, but their development is hampered by a lack of access to microfinance credit. Further, concludes that where possible SME's should be situated near financial institutions as this will foster their accessibility and evaluation by financial managers. Firms should be situated near auxiliary service providers who will offer them better financial guidance in accessing credit.

\section{Recommendations}

Owners/managers of SMEs should realize the importance of embracing financial innovations since they present a medium for the business to generate long term stability and increases the firm's capability to handle financial matters. This study further recommends that owners of SME should enhance their capital bases as this can act as security for future credit needs. SMEs should also adopt better financial records management as they are a key source of the firm's financial performance and can be used to gauge how financially sound the firms are. The study also recommends the SME managers/owners to seek investment opportunities since this is key in positioning the firm in a state where it can grow and survive conditions such as inflation and future uncertainties. Also recommends that managers/owners to develop effective business support systems which are key to the success of any investment opportunities. SMEs need to adopt a risk management strategy and methodology and that there is a need for a trade-off between receivables and holding inventory if the SMEs are to attain the required profits.

\section{References}

1) Abayo, J. A., \& Oloko, M. (2017). Effect of micro-credit on growth of small business enterprises: A case of M-Shwari at Kibuye Market in Kisumu County, Kenya. Jomo Kenyatta University of Agriculture and Technology.

2) Amoah, B., Aboagye, A. Q., Bokpin, G. A., \& Ohene-Asare, K. (2018). Firm-Specific, Financial Development and Macroeconomic Determinants of Credit Union Lending. Journal of International Development, 30(7), 1203-1222.

3) Azende, T., (2012). Risk Management and Insurance of Small and Medium Scale Enterprises (SMEs) in Nigeria. International Journal of Finance and Accounting, 1(1), 8-17.

4) Badulescu, D. (2012). Collateral in SMEs' Lending: Banks' Requirements Vs Customers' Expectations. The Journal of the Faculty of Economics. University of Oradea, 3(2) 493-499.

5) Ghimire, B., \& Abo, R. (2013). An empirical investigation of Ivorian SMEs access to bank finance: Constraining factors at demand-level. Journal of finance and investment analysis, 2(4), 29-55.

6) Gichuki, A., Njeru, A., \& Tirimba, O. (2014). Challenges Facing Micro and Small Enterprises in Accessing Credit Facilities in Kangemi Harambee Market in Nairobi City County, Kenya.

7) Githui O. (2012), "The impact of credit risk management on financial performance of commercial banks in Kenya" (Unpublished MBA Thesis). University of Nairobi.

8) Iopev, L., \& Kwanum, I. M. (2012). An assessment of risk management of small and medium scale enterprises in Nigeria. Research Journal of Finance and Accounting, 3(5), 151-159.

9) Kanyare, N., \& Mungai, J. (2017). Access to microcredit determinants and financial performance of small and medium retailing enterprises in Wajir county, Kenya. International Journal of Finance, 2(6), 103-136.

10) Kithinji, A.M. (2010). Credit Risk Management and Profitability of Commercial Banks in Kenya, (Unpublished MBA Project), School of Business, University of Nairobi, Kenya.

11) Mugenda, A. G. (2013). Qualitative research methods.

12) Muguchu, M. (2013). Relationship between access to credit and financial performance of small and medium enterprises in Nairobi, Kenya. Unpublished MBA Project.

13) Muturi, E., \& Rotich, G. (2016). Effect of Credit Management Practices on Loan Performance in Deposit Taking Microfinance Banks in Kenya. International Journal of Innovations, Business and Management (IJIBM), 10(1). 
14) Nkuah, J. K., Tanyeh, J. P., \& Gaeten, K. (2013). Financing small and medium enterprises (SMEs) in Ghana: challenges and determinants in accessing bank credit. International Journal of Research in Social Sciences, 2(3), 12-25.

15) Onaolapo, A. R. (2012), "Analysis of credit risk management efficiency in Nigerian commercial banking sector" Far East Journal of Marketing and Management, 1 (5).

16) Quartey, P., Turkson, E., Abor, J. Y., \& Iddrisu, A. M. (2017). Financing the growth of SMEs in Africa: What are the constraints to SME financing within ECOWAS? Review of development finance, 7(1), 18-28.

17) Shah, A., \& Braganza, M. F. (2013). Factors influencing the uptake of loans: A correlation descriptive Analysis. International Conference on Industrial Engineering and Operations Management, (pp. 492-498). Britain.

18) Vera, D., \& Onji, K. (2010). Changes in the Banking System and Small Business Lending. Small Business Economics, 34(3), 293-308.

19) Waari, D. N., \& Mwangi, W. M. (2015). Factors influencing access to finance by micro, small and medium enterprises in Meru County, Kenya. International Journal of Economics, Commerce and Management, 3(4), 1-15.

20) Wanjohi, A. M. (2010). Challenges Facing SMEs in Kenya and the Efforts in Progress. SME PAPERS

21) World Bank. (2015). Small and Medium Enterprises (SMEs) Finance. Washington, D.C 